Supporting Information

\title{
Sequestration of Antimonite by Zerovalent Iron: Using Weak Magnetic Field Effects to Enhance Performance and Characterize Reaction Mechanisms
}

\author{
Chunhua Xu ${ }^{l}$, Bingliang Zhang ${ }^{l}$, Liujia Zhu ${ }^{l}$, Sheng Lin ${ }^{l}$, \\ Xueping Sun ${ }^{2}$, Zheng Jiang ${ }^{2}$, and Paul G. Tratnyek ${ }^{3}$ * \\ ${ }^{1}$ School of Environmental Science and Engineering \\ Shandong University, Jinan, \\ Shandong, 250100, China \\ ${ }^{2}$ Shanghai Synchrotron Radiation Facility \\ Shanghai Institute of Applied Physics \\ Chinese Academy of Sciences, Shanghai 201204, PR China \\ ${ }^{3}$ Institute of Environmental Health \\ Oregon Health \& Science University \\ 3181 SW Sam Jackson Park Road, Portland, OR 97239 \\ *Corresponding authors:
}

Email:xuchunhua@sdu.edu.cn, Phone: 86-531-88362586,Fax: 86-531-88364513

Email: tratnyek@ohsu.edu, Phone: 503-346-3431, Fax: 503-346-3427

\section{Contents}

Eh-pH diagram for Sb-Fe-water system (Figure S1).....

S2

Properties and prior results with Alfa-Aeser ZVI (Table S1-S2)....................................... S3

Summary of rate constants from fitting $\mathrm{Sb}$ removal data (Table S3) .................................. S6

Time series data for various treatment effects (Figure S2-S5) ………………………....... S8

XPS spectra (Figure S6-S7) ................................................................................... S10

XANES and EXAFS methods and analysis (Figure S8, Table S4).................................... S12

Kinetic data for WMF effects on metalloid oxyanion anion removal (Table S5) ................ S S15

References for Supporting Information ………………........................................... S18 


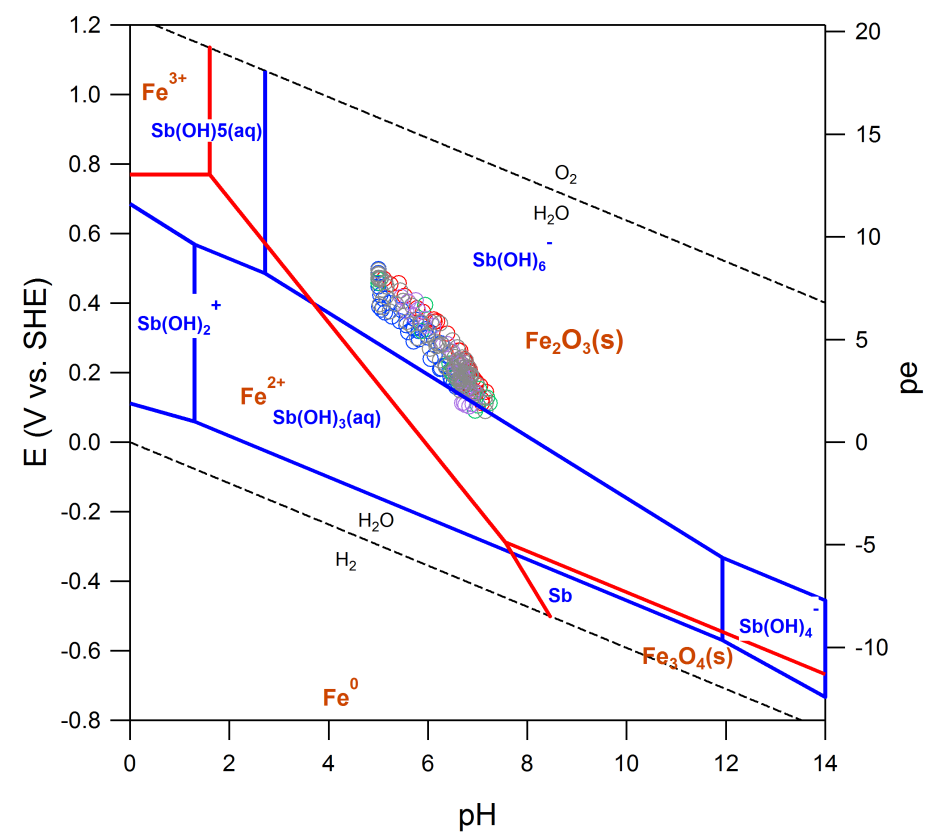

Figure S1. Eh-pH diagram for species of $\mathrm{Sb}(\mathrm{III})$ and iron $(\mathrm{Fe}(\mathrm{II})=1 \mathrm{mg} / \mathrm{L} ; \mathrm{Sb}(\mathrm{III})=1 \mathrm{mg} / \mathrm{L} ; 1$ $\mathrm{mM} \mathrm{Na}_{2} \mathrm{SO}_{4}$; Temperature $=298 \mathrm{~K}$; Suppressed iron phases: pyrite, pyrrhotite, and troilite . Speciation modeling for iron performed using the Geochemist's Workbench modeling package (RockWare Inc., Golden, $\mathrm{CO}$ ). Circles are $\mathrm{Eh}$ and $\mathrm{pH}$ data from time series data ZVI aging (Figure 3, main text), added $\mathrm{Fe}^{2+}$ (Figure S3), and mixing rate (Figure S4). Not shown in this figure: IPA, IPA and aging time, and IPA and added $\mathrm{Fe}^{2+}$. 


\section{Properties of Alfa-Aesar Zerovalent Iron}

The zerovalent iron used in this study was Alfa-Aesar, Catalog Number 00737. The specific sample was lot number G15Z026, acquired (in China) in March 2014. Manufacturer provided data on this material include grain size $=200$ mesh and purity $=99+\%$ (metals basis).

As part of an on-going study to better understand the uncertainties in the specific surface area (SSA) in ZVI samples, we measured the SSA of the Alfa-Aesar ZVI sample by BET $\mathrm{N}_{2}$-gas adsorption over a range of sample preparation conditions (time and temperature under a stream of $\mathrm{N}_{2}$ ). The results, summarized below, are given with the "error" provided by the instrument (Micromeritics Gemini 5, recently refurbished and calibrated by the manufacturer), which represents only the uncertainty in fitting an isotherm to the raw data obtained for each analysis.

Table S1. BET specific surface areas (SSA) of Alfa-Aesar ZVI.

\begin{tabular}{|c|c|c|c|}
\hline Temperature $\left({ }^{\circ} \mathrm{C}\right)$ & Time (min) & $\mathrm{SSA}\left(\mathrm{m}^{2} / \mathrm{g}\right)$ & SSA Error \\
\hline 120 & 60 & 0.126 & \pm 0.002 \\
\hline 150 & 60 & 0.127 & \pm 0.008 \\
\hline 150 & 60 & 0.125 & \pm 0.002 \\
\hline 200 & 60 & 0.126 & \pm 0.002 \\
\hline 200 & 60 & 0.137 & \pm 0.001 \\
\hline 300 & 120 & 0.257 & \pm 0.036 \\
\hline
\end{tabular}

The sample prepared at the highest temperature $\left(300^{\circ} \mathrm{C}\right)$ appears to have a slightly elevated SSA, which is consistent with other data we have obtained with iron oxides (not shown). Another SSA measured on this product, completely independently by a collaborator (Xiaohong Guan, Tongji Univ.), also at a high sample preparation temperature $\left(250{ }^{\circ} \mathrm{C}\right.$ for $\left.5 \mathrm{hr}\right)$, was 0.47 $\mathrm{m}^{2} / \mathrm{g}$. Based on these and other data, we believe that the SSA measurements made with relatively low preparation temperatures are more relevant and reliable. For this particular material, the recommended value for SSA is $0.126 \mathrm{~m}^{2} / \mathrm{g}$.

Granular ZVI from Alfa-Aesar has only recently become commonly-used in laboratory studies of contaminant removal, so it is not yet fully known how its reactivity compares to that of other, more familiar types of ZVI. However, studies using Alfa-Aesar ZVI that have been reported to date (Table S1) all show effects that are typical of ZVI in general. 
Table S2. Summary of prior publications on contaminant removal with Alfa-Aesar ZVI.

\begin{tabular}{|c|c|c|c|}
\hline Reference & System & Results & Notes \\
\hline Thomas et al. $^{1}$ & $\begin{array}{l}\text { 2,4-Dinitrotoluene } \\
\text { disappearance in a } \\
\text { recirculated batch system } \\
\text { combined with ozonation }\end{array}$ & $\begin{array}{l}\text { A single-step reduction and oxidation of } 2,4-\mathrm{DNT} \text { is possible, and } \\
\text { that it is likely that mineralization of } 2,4-\mathrm{DNT} \text { is occurring. iron } \\
\text { reduced the } 2,4-\mathrm{DNT} \text { and ozone oxidized these products resulting } \\
\text { in a } 73 \% \text { removal of TOC and a } 96 \% \text { decrease in } 2,4-\mathrm{DNT} \\
\text { concentration within } 3 \text { hours. }\end{array}$ & $\begin{array}{l}\text { The ZVI species used for } \\
\text { this study was Fe } \\
(99.98 \% \text {, Alfa Aesar). }\end{array}$ \\
\hline Yoon et al. $^{2}$ & $\begin{array}{l}\mathrm{Cr}(\mathrm{VI}) \text { removal in batch tests } \\
\text { and Column experiments vs } \\
\text { pH and dissolved oxygen } \\
\text { effect }\end{array}$ & $\begin{array}{l}\mathrm{Cr}(\mathrm{VI}) \text { was entirely reduced to } \mathrm{Cr}(\mathrm{III}) \text { by } \mathrm{Fe}(0) \text { under oxic and } \\
\text { anoxic conditions, followed by rapid adsorption of } \mathrm{Cr}(\mathrm{III}) \text { onto the } \\
\mathrm{Fe}(0) \text {. The kinetics of } \mathrm{Cr}(\mathrm{VI}) \text { removal by } \mathrm{Fe}(0) \text { was greatly } \\
\text { improved by adjusting the pH to } 5 \text {, under both oxic and anoxic } \\
\text { conditions. }\end{array}$ & $\begin{array}{l}\mathrm{Fe}(0)(<200 \text { mesh, }<75 \mu \\
\mathrm{m}, 00737) \text { was obtained } \\
\text { from Alfa Aesar Chemical } \\
\text { Inc. (Ward Hill, MA, } \\
\text { USA). }\end{array}$ \\
\hline Sun et al. ${ }^{3}$ & $\begin{array}{l}\text { Reduction of } \mathrm{As}(\mathrm{V}) \text { to } \mathrm{As}(\mathrm{III}) \\
\text { using strictly anoxic } \\
\text { conditions }\end{array}$ & $\begin{array}{l}\mathrm{As}(\mathrm{V}) \text { removal capacity on acid-treated } \mathrm{ZVI} \text { was } \sim 10 \text { times higher } \\
\text { than commercial ZVI of similar size. } \mathrm{Fe}(0) \text { core of } Z \mathrm{VI} \text { is } \\
\text { necessary for reduction of } \mathrm{As}(\mathrm{V}) .\end{array}$ & $\begin{array}{l}\text { Commercial ZVI (Alfa- } \\
\text { Aesar, } 99.2 \% \text { Fe and } \sim 0.3 \\
\text { mm diameter) } \\
\text { was used as received and } \\
\text { also after acid pre- } \\
\text { treatment. }\end{array}$ \\
\hline Tang et al. ${ }^{4}$ & $\begin{array}{l}\text { Selenite removal by ZVI in } \\
\text { anaerobic condition promoted } \\
\text { by } \mathrm{Co}^{2+} \text { and } \mathrm{Mn}^{2+}\end{array}$ & $\begin{array}{l}\mathrm{Co}^{2+} \text { and } \mathrm{Mn}^{2+} \text {, especially the former, significantly enhanced } \\
\text { selenate removal by } \mathrm{ZVI} . \mathrm{Co}^{2+} \text { promoted } \mathrm{Fe}^{2+} \text { release and the } \\
\text { formation of a bimetallic }\left(\mathrm{Co}^{0}-\mathrm{Fe}^{0}\right) \text { catalytic system by redox } \\
\text { reaction. } \mathrm{Co}^{2+} \text { and } \mathrm{Mn}^{2+} \text { provided around } 69 \% \text { and } 30 \% \text { electron } \\
\text { for selenate reduction, respectively. Selenite }\left(\mathrm{Se}^{\mathrm{IV}}\right) \text { was the } \\
\text { predominant reductive product in the presence of } \mathrm{Co}^{2+} \text {; however, } \\
\text { selenite and elemental Se }\left(\mathrm{Se}^{0}\right) \text { were the main reductive products } \\
\text { in the presence of } \mathrm{Mn}^{2+} \text {. }\end{array}$ & $\begin{array}{l}\text { ZVI grain of } 20-\mathrm{mesh} \\
(0.83 \mathrm{~mm})(>99.2 \%, \text { Alfa } \\
\text { Aesar) has a specific } \\
\text { surface area of } 0.073 \mathrm{~m}^{2} \\
\text { /g by BET nitrogen } \\
\text { absorption analysis } \\
\text { (Autosorb-6, } \\
\text { Quantachrome, USA). }\end{array}$ \\
\hline Yoon et al. $^{5}$ & $\begin{array}{l}\text { Selenate removal by ZVI in } \\
\text { oxic condition in batch } \\
\text { experiments }\end{array}$ & $\begin{array}{l}\mathrm{Se}(\mathrm{VI}) \text { is removed can be increased by increasing the } \mathrm{Fe}(\mathrm{II}) \\
\text { concentration under oxic condition, the addition of } \mathrm{Fe}(\mathrm{II}) \\
\text { enhanced the reactivity of } \mathrm{ZVI} \text { through the formation of iron } \\
\text { oxides (magnetite) favoring electron transfer during the removal } \\
\text { of } \mathrm{Se}(\mathrm{VI}) \text {. }\end{array}$ & \\
\hline Yoon et al. $^{6}$ & $\begin{array}{l}\text { Reduction and adsorption of } \\
\text { selenite in batch experiments }\end{array}$ & $\begin{array}{l}\text { Correlation coefficients }\left(\mathrm{r}^{2}\right) \text {, pseudo-first-order rate constants }(k) \text {, } \\
\text { and half-lives }\left(t_{1 / 2}\right) \text {, for } \mathrm{Se}(\mathrm{VI}) \text { removal by ZVI, triplicate } \\
\text { experiment. }\end{array}$ & $\begin{array}{l}\text { ZVI }(<200 \text { mesh, }<75 \mu \mathrm{m}) \\
\text { was obtained from Alfa } \\
\text { Aesar. The iron grains } \\
\text { were irregularly shaped. }\end{array}$ \\
\hline
\end{tabular}




\begin{tabular}{|c|c|c|c|c|c|c|c|c|}
\hline & & & $\mathrm{pH}$ & $\mathrm{Se}(\mathrm{mg} / \mathrm{L})$ & $\mathrm{r}^{2}$ & $k\left(\mathrm{~h}^{-1}\right)$ & $t_{1 / 2}(\mathrm{~h})$ & \multirow{11}{*}{$\begin{array}{l}\text { with a BET surface area } \\
\text { of } 0.3590 \mathrm{~m}^{2} / \mathrm{g} \text {. }\end{array}$} \\
\hline & & oxic & 4 & 10 & 0.932 & 1.122 & 0.634 & \\
\hline & & oxic & 6 & 10 & 0.896 & 0.602 & 1.167 & \\
\hline & & oxic & 8 & 10 & 0.962 & 0.255 & 2.728 & \\
\hline & & oxic & 10 & 10 & 0.985 & 0.119 & 5.942 & \\
\hline & & oxic & 6 & 25 & 0.916 & 0.584 & 1.187 & \\
\hline & & oxic & 6 & 50 & 0.989 & 0.092 & 7.533 & \\
\hline & & oxic & 6 & 100 & 0.980 & 0.053 & 13.075 & \\
\hline & & Anoxic & 6 & 10 & NA & NA & NA & \\
\hline & & Anoxic & 8 & 10 & NA & NA & NA & \\
\hline & & $\begin{array}{l}\text { The mai } \\
\text { corrosio } \\
\text { concent } \\
\text { and mag } \\
\text { adsorbe } \\
\text { Se(VI) }\end{array}$ & $\begin{array}{l}\text { acto } \\
\text { oati } \\
\text { ions, } \\
\text { tite } \\
\text { n th } \\
\text { cent }\end{array}$ & $\begin{array}{l}\mathrm{Se}(\mathrm{VI}) \mathrm{rec} \\
\text { as } \mathrm{Se}(\mathrm{VI}) \\
\mathrm{VI}) \text { was co } \\
\text { formed. Ho } \\
\text { I surface a } \\
\text { ns. }\end{array}$ & $\begin{array}{l}\text { and ad } \\
\text { tration } \\
\text { ly redu } \\
\mathrm{Se}(\mathrm{VI} \\
\text { docroc }\end{array}$ & $\begin{array}{l}\text { ption ar } \\
\text { low Se } \\
\text { to } \mathrm{Se}(\mathrm{C} \\
\text { e(IV) w } \\
\text { was for }\end{array}$ & $\begin{array}{l}\text { iron } \\
\text { I) } \\
\mathrm{Se}(-\mathrm{II}) \text {, } \\
\text { partially } \\
\text { ed in high }\end{array}$ & \\
\hline Noradoun et al. ${ }^{7}$ & $\begin{array}{l}\text { Detoxification of malathion a } \\
\text { chemical warfare agent }\end{array}$ & $\begin{array}{l}\text { Degrada } \\
\text { containi } \\
\text { air and } \\
\text { GCFID. } \\
\text { pseudo- } \\
\text { rate con }\end{array}$ & $\begin{array}{l}\text { n of } \\
0.50 \\
\text { ssur } \\
\text { he de } \\
\text { st-or } \\
\text { nt o }\end{array}$ & $\begin{array}{l}\text { mM mala } \\
\text { ranular zer } \\
\text { s complete } \\
\text { lation kine } \\
\text { vith respec } \\
2 \mathrm{~h}^{-1} \text {. }\end{array}$ & $\begin{array}{l}\mathrm{h} \text { a } 10 \\
\mathrm{t} \text { iron } \\
\mathrm{h} \text { to th } \\
\text { nonstr: } \\
\text { lathion }\end{array}$ & $\begin{array}{l}\text { aqueou } \\
\text { I) unde } \\
\text { etection } \\
\text { the syst } \\
\text { appear }\end{array}$ & $\begin{array}{l}\text { olution } \\
\text { Imbient } \\
\text { mit of } \\
\text { a to be } \\
\text { ce with a }\end{array}$ & $\begin{array}{l}\text { Iron particles, } 0.5 \mathrm{~g}(40- \\
70 \text { mesh, } 99 \% \text {, Alfa- } \\
\text { Aesar, Ward Hill, } \\
\text { MA). }\end{array}$ \\
\hline
\end{tabular}


Table S3. Rate constants for Sb(III) removal by ZVI.

\begin{tabular}{|c|c|c|c|c|}
\hline \multirow{2}{*}{ Group } & & \multicolumn{2}{|c|}{$k_{\mathrm{obs}}\left(\min ^{-1}\right)$} & \multirow{2}{*}{ Reaction conditions } \\
\hline & & $+\mathrm{WMF}$ & $-\mathrm{WMF}$ & \\
\hline \multirow{4}{*}{$\begin{array}{l}\mathrm{pH} \\
\text { (Fig. S2) }\end{array}$} & $\mathrm{pH}=3$ & 0.0165 & 0.0104 & \multirow{4}{*}{$\begin{array}{l}\text { Open batch reactors, } \\
{[\mathrm{ZVI}]=0.1 \mathrm{~g} / \mathrm{L},} \\
{[\mathrm{Sb}(\mathrm{III})]=1 \mathrm{mg} / \mathrm{L},} \\
\mathrm{RPM}=400, \text { no buffer. } \\
\text { Treatment variable }= \\
\text { pH. }\end{array}$} \\
\hline & $\mathrm{pH}=5$ & 0.0189 & 0.0023 & \\
\hline & $\mathrm{pH}=7$ & 0.0110 & 0.0015 & \\
\hline & $\mathrm{pH}=9$ & 0.0140 & 0.0033 & \\
\hline \multirow{3}{*}{$\begin{array}{l}\text { Initial Sb(III) } \\
\text { (Fig. S2) }\end{array}$} & $1 \mathrm{mg} / \mathrm{L}$ & 0.0158 & 0.0021 & \multirow{3}{*}{$\begin{array}{l}\text { Open batch reactors, } \\
{[\mathrm{ZVI}]=0.1 \mathrm{~g} / \mathrm{L}, \mathrm{RPM}} \\
=400, \mathrm{pH}=5, \text { no } \\
\text { buffer. Treatment } \\
\text { variable }=[\mathrm{Sb}(\mathrm{III})] .\end{array}$} \\
\hline & $5 \mathrm{mg} / \mathrm{L}$ & 0.0127 & 0.0020 & \\
\hline & $10 \mathrm{mg} / \mathrm{L}$ & 0.0037 & -- & \\
\hline \multirow{6}{*}{$\begin{array}{l}\text { Coexisting } \\
\text { anions } \\
\text { (Fig. S2) }\end{array}$} & $1 \mathrm{mM}$ Silicate & 0.0072 & -- & \multirow{6}{*}{$\begin{array}{l}\text { Open batch reactors, } \\
{[\mathrm{ZVI}]=0.1 \mathrm{~g} / \mathrm{L}, \mathrm{RPM}} \\
=400, \mathrm{pH}=5, \text { no } \\
\text { buffer. Treatment } \\
\text { variable }=\text { [anions }] .\end{array}$} \\
\hline & $1 \mathrm{mM}$ chloride & 0.0162 & -- & \\
\hline & $10 \mathrm{mM}$ chloride & 0.0172 & -- & \\
\hline & $1 \mathrm{mM}$ nitrate & 0.0171 & -- & \\
\hline & $10 \mathrm{mM}$ nitrate & 0.0165 & -- & \\
\hline & $1 \mathrm{mM}$ sulfate & 0.0175 & -- & \\
\hline \multirow{4}{*}{$\begin{array}{l}\text { Aging time } \\
\text { (Fig. 1,3) }\end{array}$} & $0 \min$ & 0.0153 & 0.0012 & \multirow{4}{*}{$\begin{array}{l}\text { Open batch reactors, } \\
{[\mathrm{ZVI}]=0.1 \mathrm{~g} / \mathrm{L},} \\
{[\mathrm{Sb}(\mathrm{III})]=1 \mathrm{mg} / \mathrm{L},} \\
\mathrm{RPM}=400, \mathrm{pH}=5, \\
\text { with no buffer. } \\
\text { Treatment variable }= \\
\text { aging time. }\end{array}$} \\
\hline & $10 \mathrm{~min}$ & 0.0168 & 0.0020 & \\
\hline & $20 \mathrm{~min}$ & 0.0179 & 0.0025 & \\
\hline & $30 \mathrm{~min}$ & 0.0163 & 0.0026 & \\
\hline \multirow{4}{*}{$\begin{array}{l}\text { Added } \mathrm{Fe}^{2+} \\
\text { (Fig. S3) }\end{array}$} & $0 \mathrm{mg} / \mathrm{L}$ & 0.0153 & 0.0012 & \multirow{4}{*}{$\begin{array}{l}\text { Open batch reactors, } \\
{[\mathrm{ZVI}]=0.1 \mathrm{~g} / \mathrm{L},} \\
{[\mathrm{Sb}(\mathrm{III})]=1 \mathrm{mg} / \mathrm{L}, \mathrm{pH}} \\
=5, \mathrm{RPM}=400, \text { with } \\
\text { no buffer. Treatment } \\
\text { variable }=\left[\mathrm{Fe}^{2+}\right] .\end{array}$} \\
\hline & $2 \mathrm{mg} / \mathrm{L}$ & 0.0171 & 0.0018 & \\
\hline & $4 \mathrm{mg} / \mathrm{L}$ & 0.0195 & 0.0030 & \\
\hline & $6 \mathrm{mg} / \mathrm{L}$ & 0.0217 & 0.0014 & \\
\hline \multirow{4}{*}{$\begin{array}{l}\text { Mixing rate } \\
\text { (Fig. S4) }\end{array}$} & 200 RPM & 0.0128 & -- & \multirow{4}{*}{$\begin{array}{l}\text { Open batch reactors, } \\
{[\mathrm{ZVI}]=0.1 \mathrm{~g} / \mathrm{L}, \mathrm{RPM}} \\
=400, \mathrm{pH}=5, \text { no } \\
\text { buffer. Treatment } \\
\text { variable = RPM. }\end{array}$} \\
\hline & 300 RPM & 0.0158 & -- & \\
\hline & 400 RPM & 0.0149 & -- & \\
\hline & $500 \mathrm{RPM}$ & 0.0175 & -- & \\
\hline
\end{tabular}




\begin{tabular}{|c|c|c|c|c|}
\hline \multirow{5}{*}{$\begin{array}{l}\text { Isopropanol } \\
\text { (Fig. S5-A) }\end{array}$} & $5 \mathrm{mM}$ & 0.0193 & 0.0024 & \multirow{5}{*}{$\begin{array}{l}\text { Open batch reactors, } \\
{[\mathrm{ZVI}]=0.1 \mathrm{~g} / \mathrm{L}, \mathrm{RPM}} \\
=400, \mathrm{pH}=5, \text { no } \\
\text { buffer. Treatment } \\
\text { variable }= \\
\text { [Isopropanol]. }\end{array}$} \\
\hline & $1 \mathrm{mM}$ & 0.0180 & -- & \\
\hline & $10 \mathrm{mM}$ & 0.0173 & -- & \\
\hline & $10 \mathrm{mM}$ & 0.0158 & -- & \\
\hline & $100 \mathrm{mM}$ & 0.0150 & -- & \\
\hline $\begin{array}{l}\text { Isopropanol + } \\
\text { Aging time } \\
\text { (Fig. S5-B) }\end{array}$ & $5 \mathrm{mM}$ & 0.0239 & 0.0032 & $\begin{array}{l}\text { Same as } \\
\text { "Isopropanol", aging } \\
\text { time is } 20 \mathrm{~min} .\end{array}$ \\
\hline $\begin{array}{l}\text { Isopropanol + } \\
\text { Added } \mathrm{Fe}^{2+} \\
\text { (Fig. S5-C) }\end{array}$ & $5 \mathrm{mM}$ & 0.0187 & 0.0023 & $\begin{array}{l}\text { Same as } \\
\text { "Isopropanol", }\left[\mathrm{Fe}^{2+}\right] \\
=2 \mathrm{mg} / \mathrm{L} .\end{array}$ \\
\hline
\end{tabular}



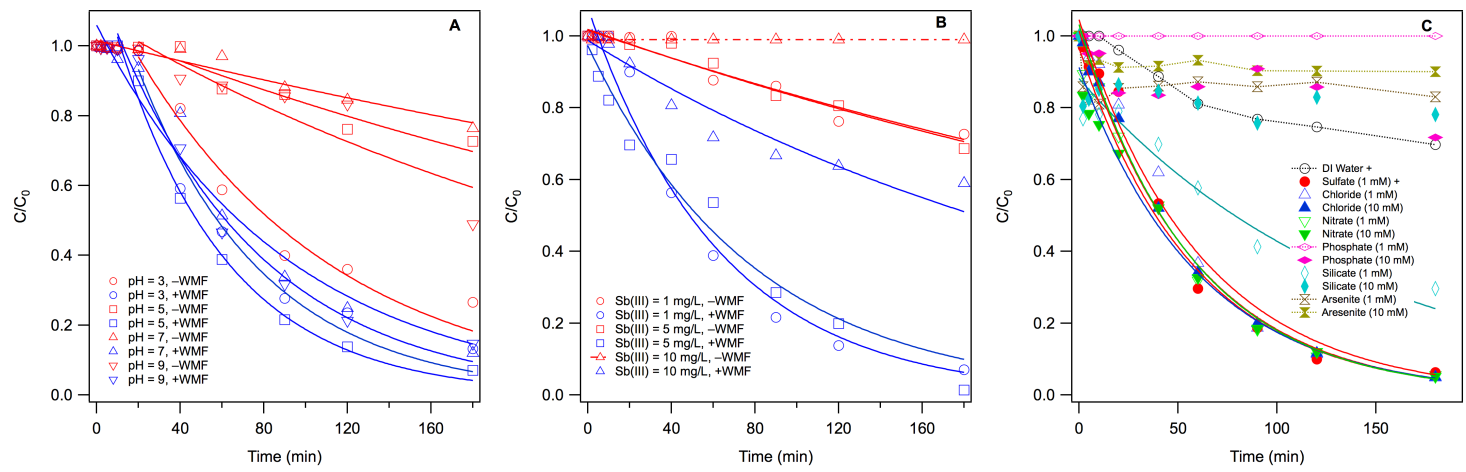

Figure S2. Time series plots showing the effect of $\mathrm{pH}$, initial $\mathrm{Sb}(\mathrm{III})$, and coanions on $\mathrm{Sb}$ (III) removal by ZVI. All of these data were obtained from stirred, open batch reactors with $0.1 \mathrm{~g} / \mathrm{L}$ ZVI. Continuous curves represent the fits to pseudo first-order kinetics, whereas the other data were not modeled and the lines only connect data points. Fitted $k_{\mathrm{obs}}$ are given in Table S3 and shown in Figure 2.
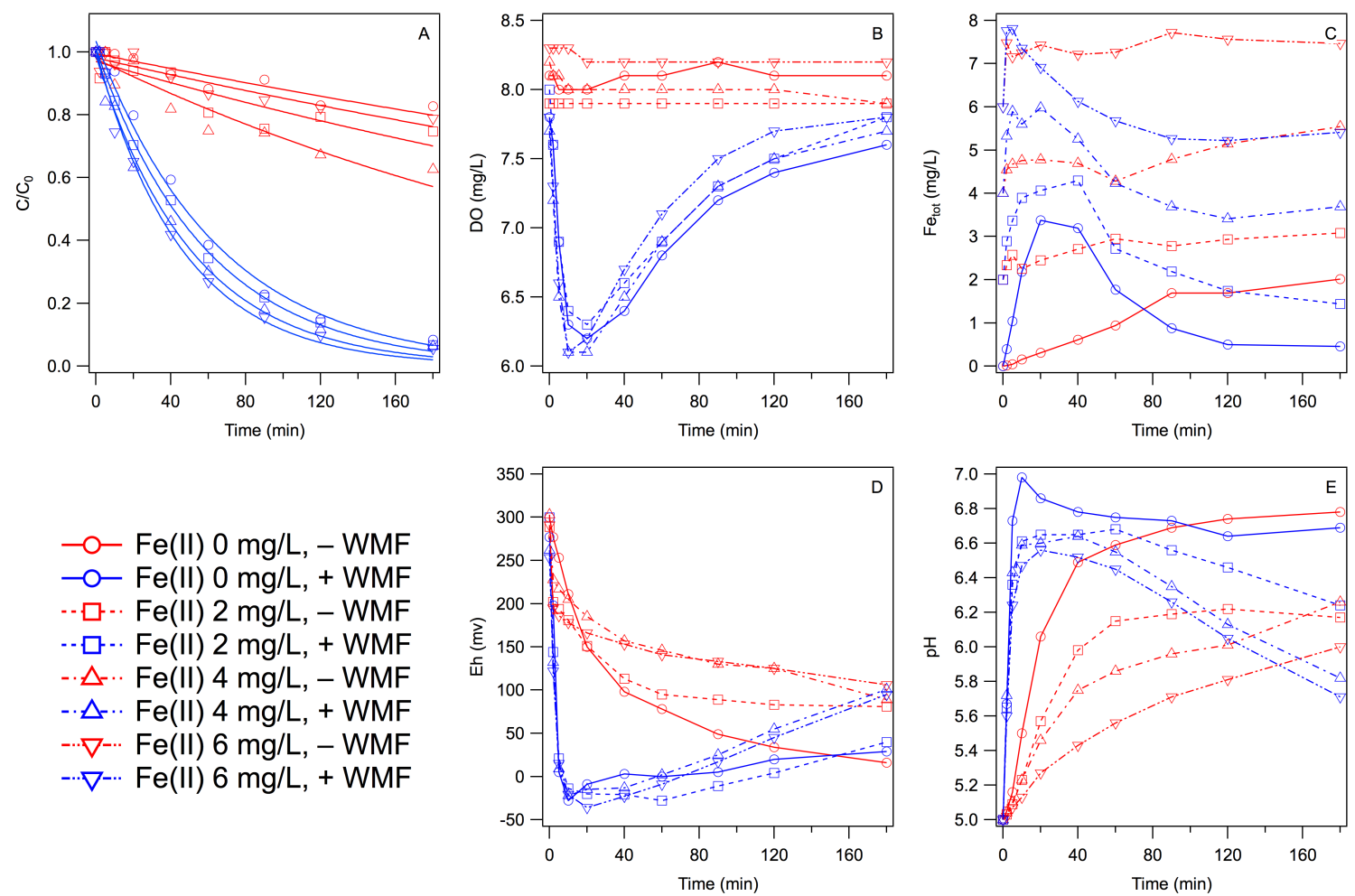

Figure S3. Time series plots showing the effect of adding $\mathrm{Fe}^{2+}$ and WMF on (A) $\mathrm{Sb}(\mathrm{III})$ removal by $\mathrm{ZVI}$ and (B-E) DO, $\mathrm{Fe}_{\text {tot }}$, $\mathrm{Eh}$, and $\mathrm{pH}$. All data were obtained from stirred, open batch reactors with $0.1 \mathrm{~g} / \mathrm{L} \mathrm{ZVI}, 1 \mathrm{mg} / \mathrm{L} \mathrm{Sb}(\mathrm{III}), 1 \mathrm{mM} \mathrm{Na}_{2} \mathrm{SO}_{4}, \mathrm{pH}_{\text {ini }}=5$, and $\mathrm{RPM}=400$. Continuous curves in A represent the fits to pseudo first-order kinetics, whereas the other data were not modeled and the lines only connect data points. Fitted $k_{\mathrm{obs}}$ are given in Table S3 and shown in Figure 2. 

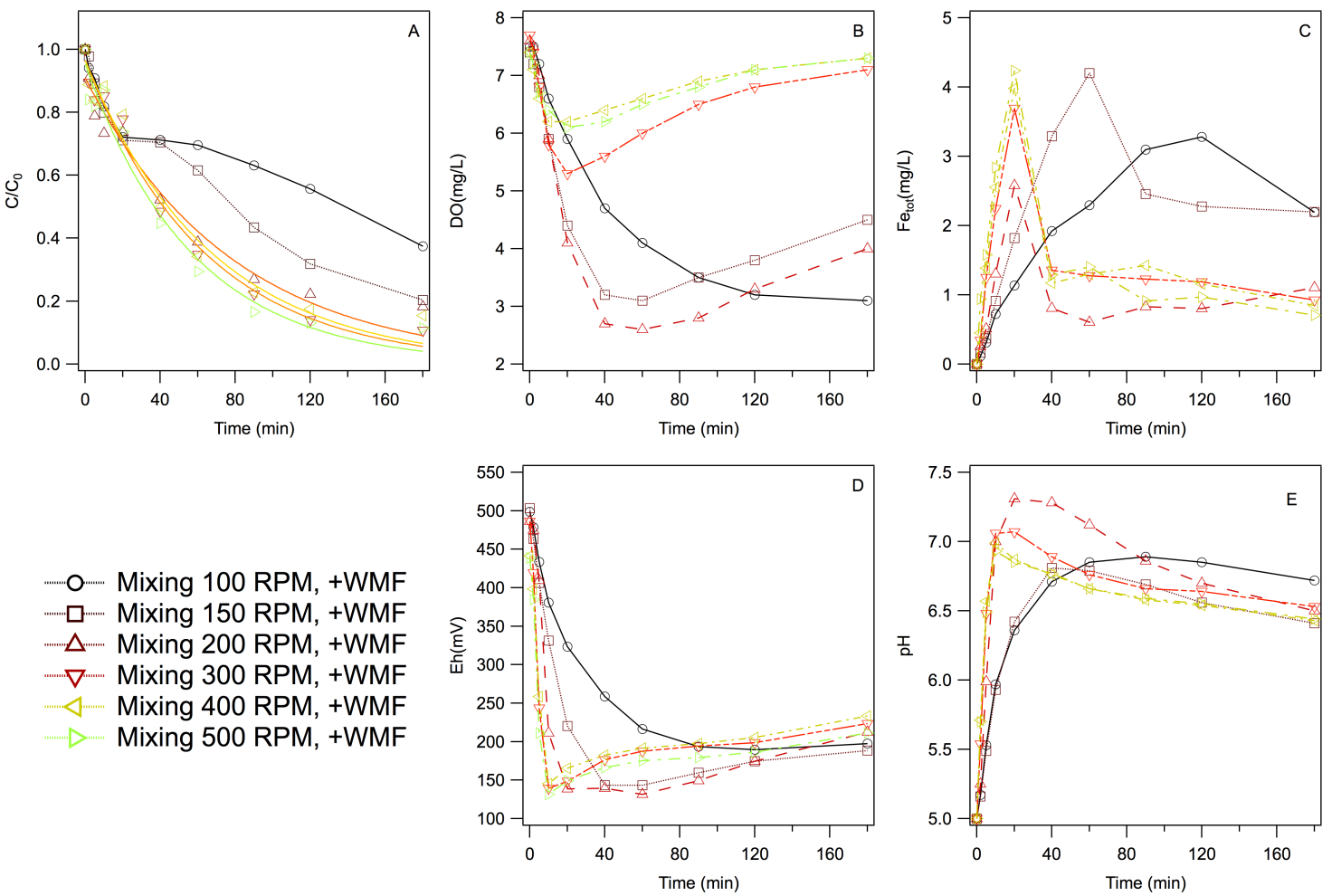

Figure S4. Time series plots showing the effect of mixing rate (RPM) and WMF on (A) Sb(III) removal by $\mathrm{ZVI}$ and (B-E) DO, Fe $e_{\text {tot }}$, Eh, and $\mathrm{pH}$. All data were obtained from stirred, open batch reactors with $0.1 \mathrm{~g} / \mathrm{L} \mathrm{ZVI,} 1 \mathrm{mg} / \mathrm{L} \mathrm{Sb}(\mathrm{III}), 1 \mathrm{mM} \mathrm{Na}_{2} \mathrm{SO}_{4}, \mathrm{pH}_{\text {ini }}=5$. Continuous curves in $\mathrm{A}$ represent the fits to pseudo first-order kinetics, whereas the other data were not modeled and the lines only connect data points. Fitted $k_{\mathrm{obs}}$ are given in Table S3 and shown in Figure 2.
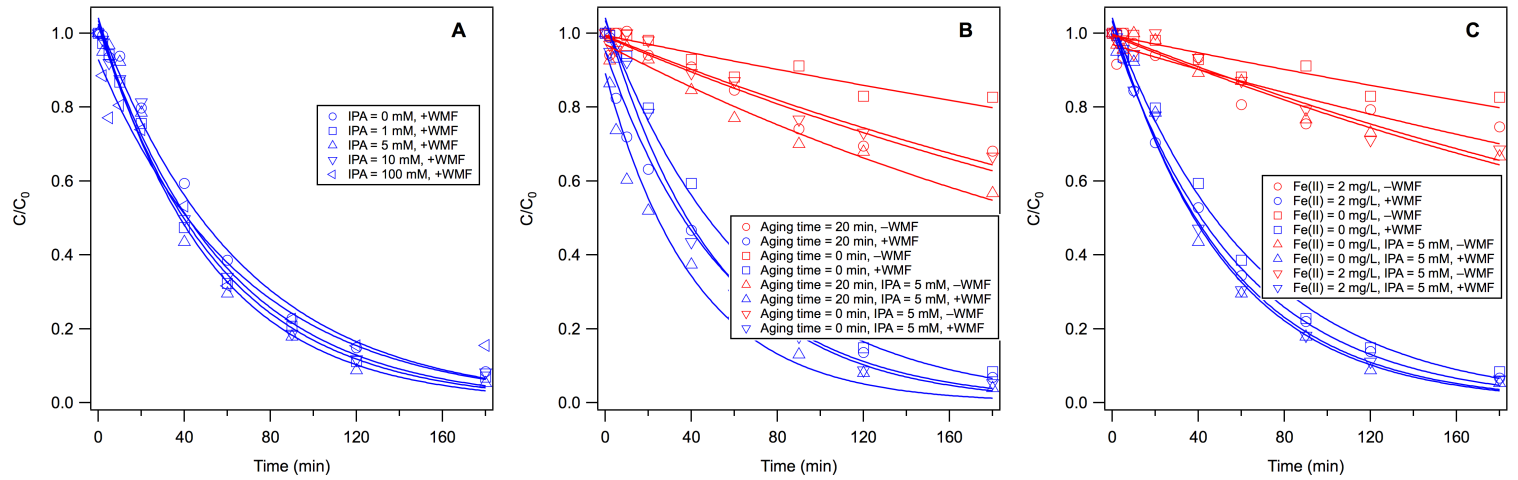

Figure S5. Time series plots showing the effect of scavenger concentration, aging time, adding $\mathrm{Fe}^{2+}$ and $\mathrm{WMF}$ on $\mathrm{Sb}(\mathrm{III})$ removal by $\mathrm{ZVI}$. All data were obtained from stirred, open batch reactors with $0.1 \mathrm{~g} / \mathrm{L} \mathrm{ZVI}, 1 \mathrm{mg} / \mathrm{L} \mathrm{Sb}(\mathrm{III}), 1 \mathrm{mM} \mathrm{Na}_{2} \mathrm{SO}_{4}, \mathrm{pH}_{\text {ini }}=5$, and $\mathrm{RPM}=400$. Continuous curves represent the fits to pseudo first-order kinetics. Fitted $k_{\mathrm{obs}}$ are given in Table S3 and shown in Figure 2. 

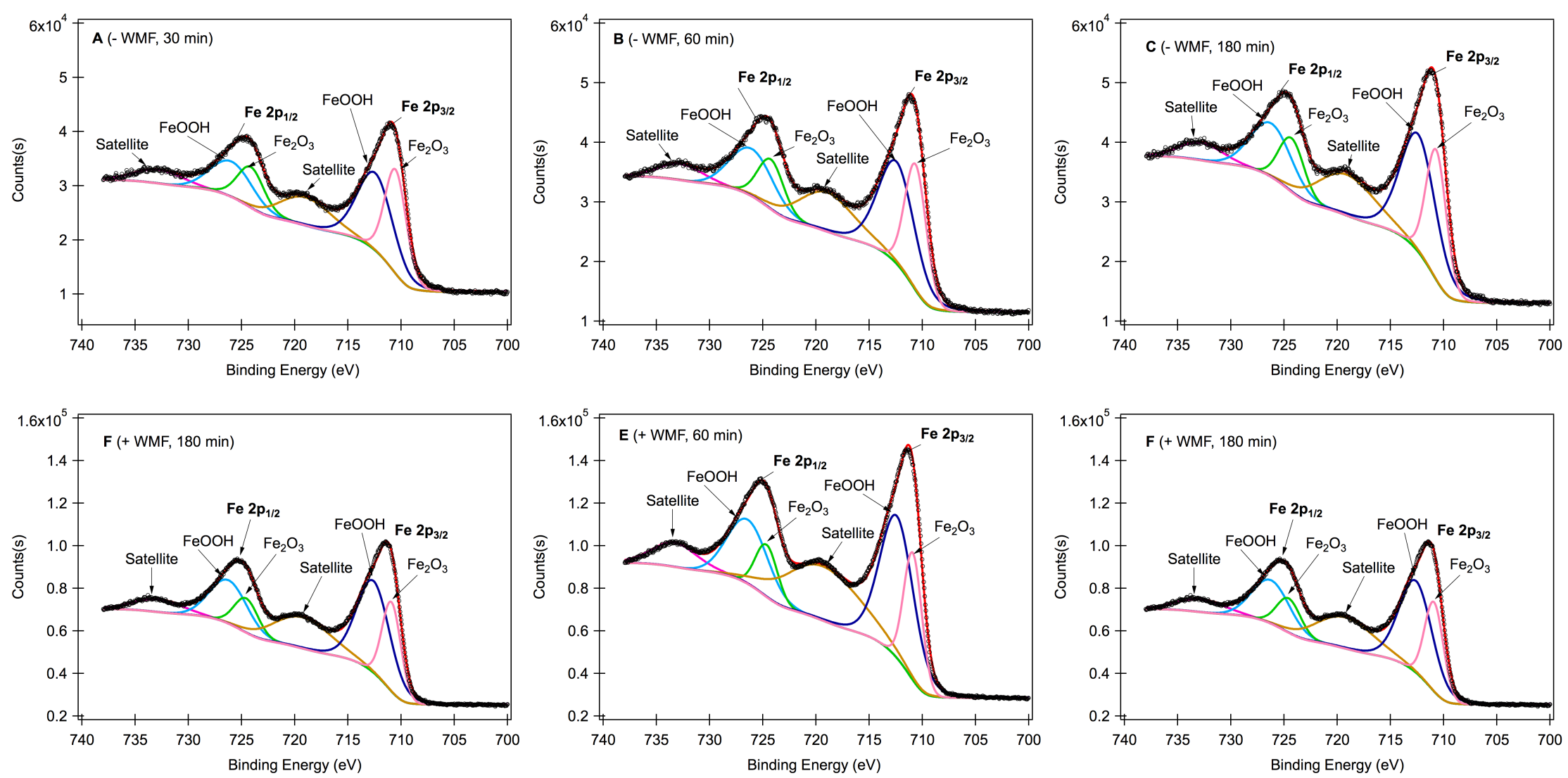

Figure S6. XPS spectra of Fe 2p: Top row, without WMF. Bottom row, with WMF. Left column, 30 min. Middle column, 60 min. Right column, $180 \mathrm{~min}$. Conditions: $\mathrm{pH}_{\text {ini }}=5, \mathrm{Sb}(\mathrm{III}) \mathrm{C}_{0}=1 \mathrm{mg} / \mathrm{L}, \mathrm{ZVI}=0.1 \mathrm{~g} / \mathrm{L}, \mathrm{RPM}=400, \mathrm{~T}=25^{\circ} \mathrm{C}$. 

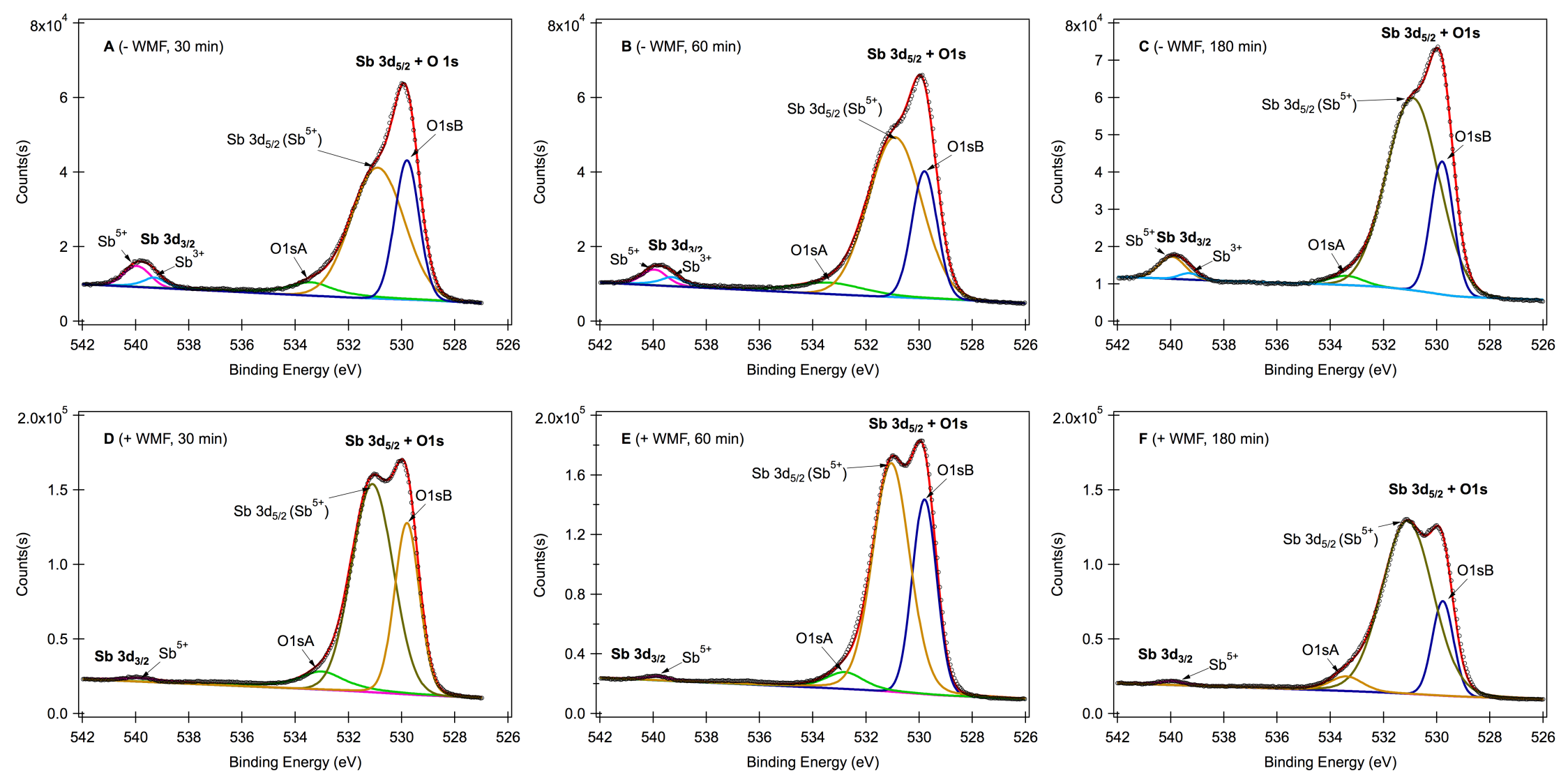

Figure S7. XPS spectra of Sb 3d: Top row, without WMF. Bottom row, with WMF. Left column, 30 min. Middle column, 60 min. Right column, $180 \mathrm{~min}$. Conditions: $\mathrm{pH}_{\text {ini }}=5, \mathrm{Sb}(\mathrm{III}) \mathrm{C}_{0}=1 \mathrm{mg} / \mathrm{L}, \mathrm{ZVI}=0.1 \mathrm{~g} / \mathrm{L}, \mathrm{RPM}=400, \mathrm{~T}=25^{\circ} \mathrm{C}$. 


\section{EXAFS Methods and Analysis}

Methods. Sb K-edge spectra were collected in fluorescence mode due to the low content of Sb in the samples, while all the reference spectra $\left(\mathrm{Sb}(0), \mathrm{K}(\mathrm{SbO}) \mathrm{C}_{4} \mathrm{H}_{4} \mathrm{O}_{6} \cdot 0.5 \mathrm{H}_{2} \mathrm{O}\right.$, and $\mathrm{KSb}(\mathrm{OH})_{6}$ were measured in transmission mode. Before measurement, the sample materials were finely crushed and pressed to form a disk, and the disk was sealed with a Kapton membrane; whereas the reference materials were prepared by placing them onto adhesive tape, uniform and separately. All the XAFS data analysis was carried out using the Ifeffit software package to calibrate energy, correct the background signal, and normalize the intensity. The normalized EXAFS function, $\chi(\mathrm{E})$, was transformed from energy space to $\mathrm{k}$-space, $\chi(\mathrm{k})$, where $\mathrm{k}$ is the photoelectron wave vector. The $\chi(\mathrm{k})$ data were multiplied by $\mathrm{K}^{3}$ to compensate for damping of EXAFS oscillations in the high K-region. The backscattering amplitude and phase shift were obtained from theoretical calculations using the FEFF code. An $\mathrm{S}_{0}{ }^{2}$ value of 0.89 was obtained by fitting data for the $\mathrm{Sb}$ standard samples. From the analysis, structural parameters, such as the coordination numbers $(\mathrm{N})$, bond distance $(\mathrm{R})$, Debye-Waller factors, and inner potential shift were calculated.

Results. XANES measurements were conducted to investigate the geometry and the electronic structure of $\mathrm{Sb}$ on ZVI that was recovered after $180 \mathrm{~min}$ of exposure to $1 \mathrm{mg} / \mathrm{L} \mathrm{Sb}(\mathrm{III})$ at $\mathrm{pH}=5$, with and without WMF. Figure S8 shows the normalized XANES of these samples, and the reference samples of $\mathrm{Sb}(\mathrm{V}), \mathrm{Sb}(\mathrm{III})$ and $\mathrm{Sb}(0)$. A comparison between the samples and references_-bulk $\mathrm{Sb}(\mathrm{V}), \mathrm{Sb}(\mathrm{III})$, and $\mathrm{Sb}(0)$ — provides evidence that the chemical state of $\mathrm{Sb}$ in both samples is similar to $\mathrm{Sb}(\mathrm{V})$ in terms of edge position and the intensity of the white line. The intensity of the white line reflects the vacancy population of the $5 p$ orbital of $\mathrm{Sb}$, whereas the position of the white line reflects the energy difference between the initial state and the final state of the excited electrons. To semi-quantitatively determine the composition of $\mathrm{Sb}$ in samples, linear combination fitting (LCF) analysis was performed on the normalized XANES for Sb Kedge (Figure S8 B, C), and the corresponding fitting results are summarized in the figures. The fraction of $\mathrm{Sb}(\mathrm{V})$ in both samples with and without WMF are obviously higher, which is in line with the results from XPS.

To further verify the atomic dispersion of $\mathrm{Sb}$ throughout the samples, Sb K-edge $\mathrm{k}^{3}-$ weighted EXAFS $\chi(\mathrm{k})$ oscillation functions and Fourier transforms (FTs) of EXAFS oscillations at the $\mathrm{Sb} \mathrm{K}$-edge were obtained (see Figure 4). For the $\mathrm{k}^{3}$-weighted $\mathrm{Sb}$ K-edge EXAFS spectra for the samples, a shoulder peak was observed at $k \approx 7 \AA^{-1}$ in spectra with magnetic field (arrows in Figure 4). 

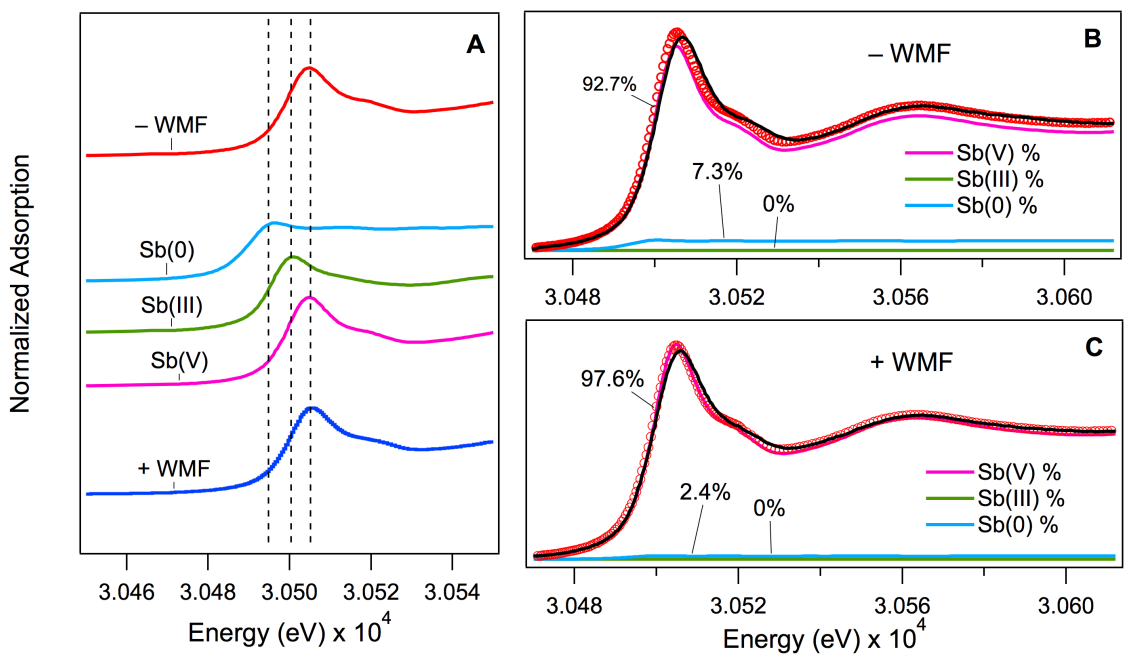

Figure S8. Sb K-edge XANES spectra and linear combination fits for Sb(III)-treated ZVI with 0.1 $\mathrm{g} / \mathrm{L} \mathrm{ZVI,} 1 \mathrm{mg} / \mathrm{L} \mathrm{Sb}(\mathrm{III}), 1 \mathrm{mM} \mathrm{Na} \mathrm{SO}_{4}, \mathrm{pH}_{\text {ini }}=5, \mathrm{t}=180 \mathrm{~min}$ ). Experimental XANES data is shown as thick black solid lines and red dashed lines represent the linear combination fits.

The FTs of the EXAFS spectra isolates the contributions of different coordination shells, in which the peak positions correspond to the interatomic distances. However, the peak positions in Figure 4B have not been corrected for the phase shift effects and thus they deviate from the real distance by $0.3-0.5 \AA$. The first prominent peak (without phase correction) around $1.7 \AA$ for both samples corresponds to the Sb-O contribution. For the sample without WMF, the second peak, at around $2.7 \AA$ and $3.1 \AA$ (with obvious splitting for the second shell) reflects $\mathrm{Sb}-\mathrm{Fe}$ contributions. In contrast, there is only one main peak for the second shell in the sample with WMF corresponding to the Sb-Fe contribution, which is in line with the analysis of $\chi(\mathrm{k})$, indicating the incorporation of $\mathrm{Sb}(\mathrm{V})$ into the iron oxide structure.

In order to further resolve the contributing factors for the second peak, we carried out the EXAFS curve-fitting (fitting parameters are given in Table S4). The quantitative analysis of the first coordination ( $\mathrm{Sb}-\mathrm{O}$ ) shell showed that all six $\mathrm{O}$ atoms were at nearly the same distance (1.94-1.95 $\AA$ ) from the central Sb. For the sample without WMF, two small peaks occurring at greater distances in the FT spectra were also isolated and fit. The fitted distances for the Sb-Fe bonds are 3.07 and $3.55 \AA$, respectively (Table S4). 
Table S4. Fitting parameters derived from EXAFS Spectra analysis at the Sb K-edge of Sb exposed ZVI with and without WMF.

\begin{tabular}{c|c|c|c|c|c|c}
\hline Sample & Shell & $\mathrm{CN}$ & $R(\AA)$ & $\Delta E_{0}(\mathrm{eV})$ & $\sigma^{2}\left(\AA^{2}\right)$ & R-factor \\
\hline \multirow{3}{*}{$-\mathrm{WMF}$} & $\mathrm{Sb}-\mathrm{O}$ & 5.5 & 1.95 & -8.0 & 0.004 & \\
& $\mathrm{Sb}-\mathrm{Fe}$ & 1.1 & 3.07 & -10.4 & 0.005 & 0.012 \\
& $\mathrm{Sb}-\mathrm{Fe}_{2}$ & 3.5 & 3.55 & -4.9 & 0.008 & \\
\hline \multirow{2}{*}{$+\mathrm{WMF}$} & $\mathrm{Sb}-\mathrm{O}$ & 5.7 & 1.94 & -10.0 & 0.004 & \multirow{2}{*}{0.015} \\
& $\mathrm{Sb}-\mathrm{Fe}$ & 2.8 & 3.10 & -3.0 & 0.005 & \\
\hline
\end{tabular}

Notes: $\mathrm{CN}$, coordination number; $R$, distance between absorber and back scatter atoms; $\sigma^{2}$, change in the Debye-Waller factor value relative to the Debye-Waller factor of the reference compound; $\Delta E_{0}$, inner potential correction to account for the difference in the inner potential between the sample and reference compound. Error bounds (accuracies) that characterize the structural parameters obtained by EXAFS spectroscopy were estimated as $\mathrm{CN}, \pm 20 \% ; R, \pm 1 \%$; $\sigma^{2}, \pm 20 \% ; \Delta E_{0}, \pm 20 \%$. R space fit, $\Delta K=2.90-13.0 \AA^{-1}, \Delta \mathrm{R}=1.0-3.8 \AA, 18$ statistically justified parameters; $\mathrm{S}_{0}{ }^{2}$ fitting from $\mathrm{Sb}$ reference samples defined as 0.89 . 
Table S5. Summary of data compiled for calculation of $R_{\mathrm{WMF}}$ for metalloids vs. ZVI.

\begin{tabular}{|c|c|c|c|c|c|c|c|c|}
\hline Cont. & Label & $+\mathbf{W M F}^{1}$ & $-\mathbf{W M F}^{1}$ & $\boldsymbol{R}_{\mathrm{WMF}}$ & $f^{(2)}$ & Treatment & Common Conditions & Ref. \\
\hline \multirow{15}{*}{$\mathrm{Sb}(\mathrm{III})$} & $\mathrm{a}$ & $k_{\mathrm{obs}}=0.0165$ & $k_{\mathrm{obs}}=0.0104$ & 1.59 & & $\mathrm{pH}=3$ & \multirow{4}{*}{$\begin{array}{l}\text { Open batch reactors, }[\mathrm{ZVI}]=0.1 \mathrm{~g} / \mathrm{L} \text {, } \\
{[\mathrm{Sb}(\mathrm{III})]=1 \mathrm{mg} / \mathrm{L}, \mathrm{RPM}=400, \text { no }} \\
\text { buffer. Treatment variable }=\mathrm{pH} .\end{array}$} & \multirow{15}{*}{$\begin{array}{l}\text { This } \\
\text { work }\end{array}$} \\
\hline & $\mathrm{b}$ & $k_{\mathrm{obs}}=0.0189$ & $k_{\mathrm{obs}}=0.0023$ & 8.22 & & $\mathrm{pH}=5$ & & \\
\hline & $\mathrm{c}$ & $k_{\mathrm{obs}}=0.0110$ & $k_{\mathrm{obs}}=0.0015$ & 7.33 & & $\mathrm{pH}=7$ & & \\
\hline & $\mathrm{d}$ & $k_{\mathrm{obs}}=0.0140$ & $k_{\mathrm{obs}}=0.0033$ & 4.24 & & $\mathrm{pH}=9$ & & \\
\hline & $\mathrm{e}$ & $k_{\mathrm{obs}}=0.0153$ & $k_{\mathrm{obs}}=0.0012$ & 12.75 & & $0 \min$ & \multirow{4}{*}{$\begin{array}{l}\text { Open batch reactors, }[\mathrm{ZVI}]=0.1 \mathrm{~g} / \mathrm{L} \text {, } \\
{[\mathrm{Sb}(\mathrm{III})]=1 \mathrm{mg} / \mathrm{L}, \mathrm{RPM}=400, \mathrm{pH}=} \\
5, \text { with no buffer. Treatment variable }= \\
\text { aging time. }\end{array}$} & \\
\hline & $\mathrm{f}$ & $k_{\mathrm{obs}}=0.0168$ & $k_{\mathrm{obs}}=0.0020$ & 8.40 & & $10 \mathrm{~min}$ & & \\
\hline & $\mathrm{g}$ & $k_{\mathrm{obs}}=0.0179$ & $k_{\mathrm{obs}}=0.0025$ & 7.16 & & $20 \mathrm{~min}$ & & \\
\hline & $\mathrm{h}$ & $k_{\mathrm{obs}}=0.0163$ & $k_{\mathrm{obs}}=0.0026$ & 6.27 & & $30 \mathrm{~min}$ & & \\
\hline & $\mathrm{i}$ & $k_{\mathrm{obs}}=0.0153$ & $k_{\mathrm{obs}}=0.0012$ & 12.75 & & $0 \mathrm{mg} / \mathrm{L}$ & \multirow{5}{*}{$\begin{array}{l}\text { Open batch reactors, }[\mathrm{ZVI}]=0.1 \mathrm{~g} / \mathrm{L} \text {, } \\
{[\mathrm{Sb}(\mathrm{III})]=1 \mathrm{mg} / \mathrm{L}, \mathrm{pH}=5, \mathrm{RPM}=} \\
400, \text { with no buffer. Treatment variable } \\
=\left[\mathrm{Fe}^{2+}\right] .\end{array}$} & \\
\hline & $\mathrm{J}$ & $k_{\mathrm{obs}}=0.0171$ & $k_{\mathrm{obs}}=0.0018$ & 9.50 & & $2 \mathrm{mg} / \mathrm{L}$ & & \\
\hline & $\mathrm{k}$ & $k_{\mathrm{obs}}=0.0186$ & $k_{\mathrm{obs}}=0.0023$ & 8.09 & & $\begin{array}{l}2 \mathrm{mg} / \mathrm{L}, 5 \mathrm{mM} \\
\text { IPA }\end{array}$ & & \\
\hline & 1 & $k_{\mathrm{obs}}=0.0195$ & $k_{\mathrm{obs}}=0.0030$ & 6.50 & & $4 \mathrm{mg} / \mathrm{L}$ & & \\
\hline & $\mathrm{m}$ & $k_{\mathrm{obs}}=0.0217$ & $k_{\mathrm{obs}}=0.0014$ & 15.50 & & $6 \mathrm{mg} / \mathrm{L}$ & & \\
\hline & $\mathrm{n}$ & $k_{\mathrm{obs}}=0.0158$ & $k_{\mathrm{obs}}=0.0021$ & 7.52 & & $\mathrm{C}_{0}=1 \mathrm{mg} / \mathrm{L}$ & \multirow{2}{*}{$\begin{array}{l}\text { Open batch reactors, }[\mathrm{ZVI}]=0.1 \mathrm{~g} / \mathrm{L} \\
\mathrm{RPM}=400, \mathrm{pH}=5, \text { no buffer. } \\
\text { Treatment variable }=[\mathrm{Sb}(\mathrm{III})]\end{array}$} & \\
\hline & $\mathrm{o}$ & $k_{\mathrm{obs}}=0.0127$ & $k_{\mathrm{obs}}=0.0020$ & 6.35 & & $\mathrm{C}_{0}=5 \mathrm{mg} / \mathrm{L}$ & & \\
\hline \multirow{4}{*}{$\mathrm{Sb}(\mathrm{V})$} & $\mathrm{p}$ & $k_{\mathrm{obs}}=0.1182$ & $k_{\mathrm{obs}}=0.0144$ & 8.21 & & $\mathrm{C}_{0}=5 \mathrm{mg} / \mathrm{L}$ & \multirow{4}{*}{$\begin{array}{l}\text { Open batch reactors, }[\mathrm{ZVI}]=1.0 \mathrm{~g} / \mathrm{L} \text {, } \\
\mathrm{pH}_{\mathrm{ini}}=4.0, \text { reaction time }=3.0 \mathrm{~h} . \\
\text { Treatment variable }=[\mathrm{Sb}(\mathrm{V})] .\end{array}$} & \multirow{4}{*}{8} \\
\hline & $\mathrm{q}$ & $k_{\mathrm{obs}}=0.0929$ & $k_{\mathrm{obs}}=0.0141$ & 6.59 & & $\mathrm{C}_{0}=10 \mathrm{mg} / \mathrm{L}$ & & \\
\hline & $\mathrm{r}$ & $k_{\mathrm{obs}}=0.0574$ & $k_{\mathrm{obs}}=0.0086$ & 6.67 & & $\mathrm{C}_{0}=20 \mathrm{mg} / \mathrm{L}$ & & \\
\hline & $\mathrm{s}$ & $k_{\mathrm{obs}}=0.0177$ & $k_{\mathrm{obs}}=0.0027$ & 6.56 & & $\mathrm{C}_{0}=40 \mathrm{mg} / \mathrm{L}$ & & \\
\hline \multirow{4}{*}{$\mathrm{Se}(\mathrm{IV})$} & A & $k_{\text {slope }}=2.10$ & $k_{\text {slope }}=1.60$ & 1.31 & 2.2 & $\mathrm{pH}=4$ & \multirow{4}{*}{$\begin{array}{l}\text { Open batch reactors, }[\mathrm{Se}(\mathrm{IV})]=40.0 \\
\mathrm{mg} / \mathrm{L},[\mathrm{ZVI}]=1.0 \mathrm{~g} / \mathrm{L} . \text { Treatment } \\
\text { variable }=\mathrm{pH} .\end{array}$} & \multirow{4}{*}{9} \\
\hline & $\mathrm{B}$ & $k_{\text {slope }}=2.70$ & $k_{\text {slope }}=1.86$ & 1.45 & 2.3 & $\mathrm{pH}=5$ & & \\
\hline & $\mathrm{C}$ & $k_{\text {slope }}=1.50$ & $k_{\text {slope }}=1.00$ & 1.50 & 2.2 & $\mathrm{pH}=6$ & & \\
\hline & $\mathrm{D}$ & $k_{\text {slope }}=1.60$ & $k_{\text {slope }}=0.10$ & 16.xx & $>$ & $\mathrm{pH}=7$ & & \\
\hline
\end{tabular}




\begin{tabular}{|c|c|c|c|c|c|c|c|c|}
\hline Cont. & Label & $+\mathrm{WMF}^{1}$ & $-\mathrm{WMF}^{1}$ & $R_{\text {WMF }}$ & $f^{(2)}$ & Treatment & Common Conditions & Ref. \\
\hline & & & & & 21.3 & & & \\
\hline & $\mathrm{E}$ & $k_{\text {slope }}=1.60$ & $k_{\text {slope }}=0.10$ & $16 . x x$ & $>12$ & $\mathrm{pH}=7.2$ & & \\
\hline & $\mathrm{F}$ & $k_{\text {slope }}=19.50$ & $k_{\text {slope }}=1.20$ & 16.25 & 42.6 & $\mathrm{pH}=6$ & \multirow{4}{*}{$\begin{array}{l}{[\mathrm{Se}(\mathrm{IV})]=5.0-40.0 \mathrm{mg} / \mathrm{L},[\mathrm{ZVI}]=1.0} \\
\mathrm{~g} / \mathrm{L},[\text { ionic strength }]=0.01 \mathrm{~mol} / \mathrm{L} . \\
\text { Treatment variable }=[\mathrm{Se}(\mathrm{IV})] \text { and } \mathrm{pH} .\end{array}$} & \\
\hline & G & $k_{\text {slope }}=15.50$ & $k_{\text {slope }}=2.15$ & 7.21 & 4.8 & $\mathrm{pH}=6$ & & \\
\hline & $\mathrm{H}$ & $k_{\text {slope }}=12.50$ & $k_{\text {slope }}=1.70$ & 7.35 & 2.4 & $\mathrm{pH}=6$ & & \\
\hline & I & $k_{\text {slope }}=1.30$ & $k_{\text {slope }}=1.10$ & 1.18 & 2.2 & $\mathrm{pH}=6$ & & \\
\hline & 0 & $k_{\mathrm{SA}}=14.54$ & $k_{\mathrm{SA}}=1.08 \times 10^{1}$ & 1.35 & & $0 \mathrm{hr}$ & \multirow{8}{*}{$\begin{array}{l}{[\mathrm{Se}(\mathrm{IV})]=40.0 \mathrm{mg} / \mathrm{L},[\mathrm{ZVI}]=1.0 \mathrm{~g} / \mathrm{L}} \\
{[\text { ionic strength }]=0.01 \mathrm{~mol} / \mathrm{L} .} \\
\text { Treatment variable }=\text { aging time. }\end{array}$} & \multirow{8}{*}{10} \\
\hline & 6 & $k_{\mathrm{SA}}=5.75$ & $k_{\mathrm{SA}}=3.91 \times 10^{-1}$ & 14.71 & & $6 \mathrm{hr}$ & & \\
\hline & 12 & $k_{\mathrm{SA}}=4.95$ & $k_{\mathrm{SA}}=9.28 \times 10^{-2}$ & 53.34 & & $12 \mathrm{hr}$ & & \\
\hline & 24 & $k_{\mathrm{SA}}=3.40$ & $k_{\mathrm{SA}}=2.97 \times 10^{-2}$ & 114.48 & & $24 \mathrm{hr}$ & & \\
\hline & 48 & $k_{\mathrm{SA}}=3.86$ & $k_{\mathrm{SA}}=3.52 \times 10^{-2}$ & 109.66 & & $48 \mathrm{hr}$ & & \\
\hline & 60 & $k_{\mathrm{SA}}=1.29$ & $k_{\mathrm{SA}}=3.32 \times 10^{-2}$ & 38.86 & & $60 \mathrm{hr}$ & & \\
\hline & 80 & $k_{\mathrm{SA}}=1.32 \times 10^{-2}$ & $k_{\mathrm{SA}}=3.99 \times 10^{-3}$ & 3.31 & & $80 \mathrm{hr}$ & & \\
\hline & 96 & $k_{\mathrm{SA}}=3.06 \times 10^{-4}$ & $k_{\mathrm{SA}}=1.58 \times 10^{-4}$ & 1.94 & & $96 \mathrm{hr}$ & & \\
\hline \multirow{4}{*}{ As(III) } & $\mathrm{J}$ & $k_{\text {slope }}=6.40$ & $k_{\text {slope }}=2.10$ & 3.05 & & $\mathrm{pH}=3$ & \multirow{4}{*}{$\begin{array}{l}{[\mathrm{ZVI}]=0.10 \mathrm{~g} / \mathrm{L},[\mathrm{As}(\mathrm{III})]=1 \mathrm{mg} / \mathrm{L}, \mathrm{T}} \\
=25^{\circ} \mathrm{C} . \text { Treatment variable }=\mathrm{pH} .\end{array}$} & \multirow{4}{*}{11} \\
\hline & $\mathrm{K}$ & $k_{\text {slope }}=2.90$ & $k_{\text {slope }}=0.12$ & 24.17 & & $\mathrm{pH}=5$ & & \\
\hline & $\mathrm{L}$ & $k_{\text {slope }}=2.10$ & $k_{\text {slope }}=0.53$ & 3.96 & & $\mathrm{pH}=7$ & & \\
\hline & M & $k_{\text {slope }}=2.50$ & $k_{\text {slope }}=0.40$ & 6.25 & & $\mathrm{pH}=9$ & & \\
\hline \multirow{4}{*}{$\mathrm{As}(\mathrm{V})$} & $\mathrm{N}$ & $k_{\text {slope }}=7.50$ & $k_{\text {slope }}=0.80$ & 9.38 & & $\mathrm{pH}=3$ & \multirow{4}{*}{$\begin{array}{l}{[\mathrm{ZVI}]=0.10 \mathrm{~g} / \mathrm{L},[\mathrm{As}(\mathrm{III})]=1 \mathrm{mg} / \mathrm{L}, \mathrm{T}} \\
=25^{\circ} \mathrm{C} . \text { Treatment variable }=\mathrm{pH} .\end{array}$} & \multirow{4}{*}{11} \\
\hline & $\mathrm{O}$ & $k_{\text {slope }}=5.80$ & $k_{\text {slope }}=0.20$ & 29.00 & & $\mathrm{pH}=5$ & & \\
\hline & $\mathrm{P}$ & $k_{\text {slope }}=5.00$ & $k_{\text {slope }}=0.28$ & 17.86 & & $\mathrm{pH}=7$ & & \\
\hline & Q & $k_{\text {slope }}=5.00$ & $k_{\text {slope }}=0.15$ & 33.33 & & $\mathrm{pH}=9$ & & \\
\hline \multirow{5}{*}{$\mathrm{Cr}(\mathrm{VI})$} & $\mathrm{R}$ & $k_{\text {slope }}=0.90$ & $k_{\text {slope }}=0.20$ & 4.50 & & dose $=0.05 \mathrm{~g} / \mathrm{L}$ & \multirow{4}{*}{$\begin{array}{l}\mathrm{pH}=5, \mathrm{C}_{0}=3.12 \mathrm{mg} / \mathrm{L},[\text { ionic } \\
\text { strength }]=0.01 \mathrm{~mol} / \mathrm{L} . \text { Treatment } \\
\text { variable }=[\mathrm{ZVI}] .\end{array}$} & \multirow{5}{*}{12} \\
\hline & $\mathrm{S}$ & $k_{\text {slope }}=2.80$ & $k_{\text {slope }}=1.00$ & 2.80 & & dose $=0.1 \mathrm{~g} / \mathrm{L}$ & & \\
\hline & $\mathrm{T}$ & $k_{\text {slope }}=2.80$ & $k_{\text {slope }}=1.10$ & 2.55 & & dose $=0.2 \mathrm{~g} / \mathrm{L}$ & & \\
\hline & $\mathrm{U}$ & $k_{\text {slope }}=2.60$ & $k_{\text {slope }}=0.90$ & 2.89 & & dose $=0.3 \mathrm{~g} / \mathrm{L}$ & & \\
\hline & & - & - & 2.17 & 1.20 & Different initial & $\mathrm{pH}=5,[\mathrm{ZVI}]=0.1 \mathrm{~g} / \mathrm{L},[$ ionic & \\
\hline
\end{tabular}




\begin{tabular}{|c|c|c|c|c|c|c|c|c|}
\hline Cont. & Label & $+\mathrm{WMF}^{1}$ & $-\mathrm{WMF}^{1}$ & $\boldsymbol{R}_{\mathrm{WMF}}$ & $f^{(2)}$ & Treatment & Common Conditions & Ref. \\
\hline & & - & - & 2.77 & 1.99 & \multirow[t]{3}{*}{ concentration } & \multirow{3}{*}{$\begin{array}{l}\text { strength }]=0.01 \mathrm{~mol} / \mathrm{L} . \text { Treatment } \\
\text { variable }=[\mathrm{Cr}(\mathrm{VI})] .\end{array}$} & \\
\hline & & - & - & 4.07 & 3.00 & & & \\
\hline & & - & - & 5.40 & 4.10 & & & \\
\hline & V & $k_{\text {slope }}=3.4$ & $k_{\text {slope }}=0.75$ & 4.53 & & & $\begin{array}{l}\mathrm{C}_{0}=20.8 \mathrm{mg} / \mathrm{L},[\mathrm{ZVI}]=0.2 \mathrm{~g} / \mathrm{L}, \mathrm{pH}= \\
5,[\mathrm{Cr}(\mathrm{VI})]=0.1 \mathrm{~g} / \mathrm{L},[\text { ionic strength }]= \\
0.01 \mathrm{~mol} / \mathrm{L} .\end{array}$ & 12 \\
\hline
\end{tabular}

1 Values of $k_{\text {obs }}$ from pseudo first order fits. Values of $k_{\text {slope }}$ estimated from initial rates in published concentration vs. time plots. Units are $1 / \mathrm{min}$ and $\mathrm{M} / \mathrm{min}$, respectively.

2 Values of " $f$ " as reported in original source. No adjustments were made for variations in how $f$ was defined in the original sources. 


\section{References in Supporting Information}

1. Thomas, J. M.; Hernandez, R.; Kuo, C.-H. Single-step treatment of 2,4-dinitrotoluene via zero-valent metal reduction and chemical oxidation. J. Hazard. Mater. 2008, 155, (1), $193-$ 198.

2. Yoon, I.-H.; Bang, S.; Chang, J.-S.; Kim, M. G.; Kim, K.-W. Effects of pH and dissolved oxygen on $\mathrm{Cr}(\mathrm{VI})$ removal in $\mathrm{Fe}(0) / \mathrm{H}_{2} \mathrm{O}$ systems. J. Hazard. Mater. 2011, 186, (1), 855862.

3. Sun, F.; Osseo-Asare, K. A.; Chen, Y.; Dempsey, B. A. Reduction of As(V) to As(III) by commercial ZVI or As(0) with acid-treated ZVI. J. Hazard. Mater. 2011, 196, 311-317.

4. Tang, C.; Huang, Y. H.; Zeng, H.; Zhang, Z. Promotion effect of $\mathrm{Mn}^{2+}$ and $\mathrm{Co}^{2+}$ on selenate reduction by zero-valent iron. Chem. Eng. J. 2014, 244, 97-104.

5. Yoon, I.-H.; Bang, S.; Kim, K.-W.; Kim, M. G.; Park, S. Y.; Choi, W.-K. Selenate removal by zero-valent iron in oxic condition: the role of $\mathrm{Fe}(\mathrm{II})$ and selenate removal mechanism. Environ. Sci. Pollut. R 2015, 1-10.

6. Yoon, I.-H.; Kim, K.-W.; Bang, S.; Kim, M. G. Reduction and adsorption mechanisms of selenate by zero-valent iron and related iron corrosion. Appl. Catal. B: Environ. 2011, 104, (1), 185-192.

7. Noradoun, C. E.; Mekmaysy, C. S.; Hutcheson, R. M.; Cheng, I. F. Detoxification of malathion a chemical warfare agent analog using oxygen activation at room temperature and pressure. Green Chem. 2005, 7, (6), 426-430.

8. Li, J.; Bao, H.; Xiong, X.; Sun, Y.; Guan, X. Effective Sb(V) immobilization from water by zero-valent iron with weak magnetic field. Sep. Purif. Technol. 2015, 151, 276-283.

9. Liang, L.; Sun, W.; Guan, X.; Huang, Y.; Choi, W.; Bao, H.; Li, L.; Jiang, Z. Weak magnetic field significantly enhances selenite removal kinetics by zero valent iron. Water Res. 2014, 49, 371-380.

10. Liang, L.; Guan, X.; Shi, Z.; Li, J.; Wu, Y.; Tratnyek, P. G. Coupled effects of aging and weak magnetic fields on sequestration of selenite by zero-valent iron. Environ. Sci. Technol. 2014, 48, (11), 6326-6334.

11. Sun, Y.; Guan, X.; Wang, J.; Meng, X.; Xu, C.; Zhou, G. Effect of weak magnetic field on arsenate and arsenite removal from water by zerovalent iron: an XAFS investigation. Environ. Sci. Technol. 2014, 48, (12), 6850-6858.

12. Feng, P.; Guan, X.; Sun, Y.; Choi, W.; Qin, H.; Wang, J.; Qiao, J.; Li, L. Weak magnetic field accelerates chromate removal by zero-valent iron. J. Environ. Sci. 2015, 31, 175-183. 